\title{
PRIMARY ORIGIN OF THE LIMESTONE-SHALE RHYTHM IN THE BRITISH LOWER LIAS
}

SIR,-In the Hettangian and lower Sinemurian of Britain a rhythmic succession of more or less uniformly alternating beds of limestone and shale is widely developed. The individual beds are commonly less than a foot thick and since well into the last century the origin of this rhythm has been in dispute. It has been maintained by some that the rhythm is primary, and caused by differences in sedimentation, and by others that it is secondary, and due to some form of chemical segregation of $\mathrm{CaCO}_{3}$ after deposition. During a detailed examination of the Blue Lias in Dorset, Glamorgan, and Somerset evidence has been obtained that the rhythm is, in fact, of primary origin.

Amongst those who have favoured some form of secondary origin for the rhythm four groups can be distinguished. Day (1865) and Lang (1914) suggested that all the limestones and shales of the Dorset Blue Lias had segregated in some unspecified manner from an originally homogeneous marl or ooze. Woodward (1893) and Trueman (1922) distinguished between nodular limestones and limestones with regular surfaces; the former they considered secondary and the latter primary. Richardson (1923) attempted to account for all the Lower Lias limestones of Dorset by a theory of largescale rhythmic precipitation of $\mathrm{CaCO}_{3}$ in post-Lower Lias time involving the downward migration of calcareous solutions and he drew comparison with layers of flint in the Chalk and with Liesegang rings. Shukri (1942) modified this idea slightly. Kent's views (1936), applied to the Blue Lias of the Midlands, differed fundamentally from Richardson's in that he regarded the limestones as having formed successively, comparatively soon after deposition. Only Cox (1923) has claimed positively that the rhythm is entirely primary. Thus, published opinion strongly favours the idea of some sort of secondary segregation and this was the interpretation accepted by Arkell (1933).

The following facts are considered to support an essentially primary origin for the Blue Lias rhythm:-

(1) While the limestones and marls in Dorset contain at many horizons an abundant and varied benthonic fauna, the interstratified paper shales are, for the most part, barren. Petrological investigations indicate that this is an original difference and is related to the fact that the shales were deposited under anaerobic conditions.

(ii) Throughout the Blue Lias, especially in Dorset, there occurs a variety of trace-fossils, including the U-shaped burrows of worms and Chondrites structures recently investigated by Simpson (1957). These are demonstrably due to the piping down of one variety of sediment into another. Lang, in his contribution to the discussion on Simpson's paper, appreciated that if the latter's interpretation were accepted, it would furnish clear proof of an original sedimentary rhythm. If there still remains any doubt concerning the organic origin of the mottled rocks which Simpson described, there can be none about the U-shaped burrows.

(iii) Certain of the limestones are strikingly constant and may retain their thicknesses to within an inch for many miles. A few beds, distinctive both lithologically and faunally, can be recognized in Dorset, Somerset, and Glamorgan.

The question of the nodule bands and continuous nodular limestones merits brief consideration. No clear distinction is discernible between these and most of the regular limestones. It cannot be denied that there is evidence of some $\mathrm{CaCO}_{3}$ segregation in the nodular limestones but this may have taken place very soon after deposition and been based upon a primary rhythm in the sediments. Only to this extent are such limestones secondary. 


\section{REFERENCES}

ARKell, W. J., 1933. The Jurassic System in Great Britain. Oxford. Cox, A. H., 1923. (In discussion of Richardson, 1923.)

DAY, E. C. H., 1865, On the Lower Lias of Lyme Regis. Geol. Mag., ii, $518-19$.

KENT, P. E., 1936. The Formation of the Hydraulic Limestones of the Lower Lias. Geol. Mag., Ixxiii, 476-8.

LANG, W. D., 1914. The Geology of the Charmouth Cliffs, Beach, and Foreshore. Proc. Geol. Assoc., 25, 293-360.

1924. The Blue Lias of the Devon and Dorset Coasts. ibid., 35, 169-185.

Richardoson, W. A., 1923. On the Petrology of the Shales with "Beef". Quart. Journ. Geol. Soc., lxxix, 88-98.

SHUKRI, N. M., 1942. Rhythmic Banding in the Lower Lias of England. Bull. Fac. Sci. Fouad 1 Univ. Cairo, no. 24, 66-73.

Simpson, Scotr, 1957. On the trace-fossil Chondrites. Quart. Journ. Geol. Soc., cxiii. (In the press.)

Trueman, A. E., 1922. The Liassic Rocks of Glamorgan. Proc. Geol. Assoc., $33,245-284$.

Woodward, H. B., 1893. The Jurassic Rocks of Britain. Vol. III. Mem. Geol. Surv.

Sedgwick Museum,

A. Hallam.

CAMBRIDGE.

25 th January, 1957. 